\title{
Photoactive immunoconjugate of hematoporphyrin with antibodies against vascular endothelial growth factor: preparation, physicochemical and biological properties.
}

\author{
I.O. Lisniak, N.L. Novichenko, A.A. Mamchur, M.F. Gamalia \\ R.E.Kavetsky Institute of experimental pathology, oncology and radiobiology, NASU \\ 45, Vasylkivska Str., Kyiv, Ukraine, 03022 \\ gamaleia@onconet.kiev.ua
}

\begin{abstract}
Preparation of photoimmunoconjugates on the basis of hematoporphyrin and antibodies to the vascular endothelial growth factor (VEGF) has been described. The obtained conjugate preserved physicochemical and biological properties of both protein component and porphyrin part, i.e. hematoporphirin. It was shown that accumulation of the photoimmunoconjugate with VEGF antibodies in chicken embryo membranes was 2.5 times higher at the period of neovascularization in comparison with the stabilization period.
\end{abstract}

Keywords: photodynamic therapy, angiogenesis, conjugates, hematoporphyrin, VEGF.

The low-traumatic method of photodynamic therapy (PDT) has been recently used for the treatment of malignant neoplasms. According to this method an organism with tumor is treated by photosensibilizators, which are accumulated in malignant cells making them light-sensitive. Hence, the following irradiation can selectively ruin the tumor cells. This method provides higher in damaging tumor cells selectivity comparing to the methods of radiotherapy and chemotherapy. This selectivity can be explained by higher accumulation and prolonged storage of photosensibilizator in tumor cells in comparison with normal tissues. However, it does not provide very high percentage of photosensibilizator cumulating in tumors because these compounds can be also accumulated by normal tissues. Because photosensibilizators had no satisfactory selectivity in accumulation by tumor cells, the in-

Institute of molecular biology and genetics NAS of Ukraine, 2009 vestigators made an attempt to find some new approaches for PDT that at least provide effective photosensibilizator targeting to malignant tissues.

New D. et al [1] made the first step in this direction. They showed that conjugates of hematoporphyrin chemically coupled with antibodies to specific surface tumor antigens were preferentially accumulated in tumor cells. This investigation opened a way for the target photodynamic therapy, when not only antibodies [2] but also cytokines [8], growth factors and their receptors, etc [9-13] could be used for targeting.

In recent years the antivascular effect of PDT has been intensively investigated [14].This research was directed on both the screening of new photosensibilizators, affecting the tumor vascular system, and effective photosensibilizator delivery to the vessels actively formed in a tumor. One of the perspective methods of such selective delivery is introduction 
of photosensibilizators in the form of conjugates with angiogenesis inducers and antibodies against them.

Materials and methods. Polyclonal antibodies directed against VEGF were obtained by rabbit immunization using a method of induction of local immune reaction of the lymph nodes by low dose antigen with Freund's adjuvant [15].

To obtain antibodies the murine angiogenic factor was prepared as described in [16]. Hematoporphyrin was used as a porphyrin compound of hematoporphyrin-dihydrochloride conjugate (Sigma, USA). Carbodiimide-HCL was used as a linker for the mentioned conjugate.

Conjugates of antibodies with porphyrin compounds were obtained according to the following scheme [1]: $20 \mathrm{~g}$ of hematoporphyrin was diluted in 3 $\mathrm{ml}$ of the solvent (water: dimethyl formamide, 2.5:0.5). $20 \mathrm{mg}$ of 1-ethyl-3-(3-dimethylaminopropil)dimethylcarbodiimide diluted in $0.5 \mathrm{ml}$ of water was added to the porphyrin solution. The solutions of hematoporphyrin and linker were mixed and stayed at room temperature for $30 \mathrm{~min}$. After reaction $900 \mathrm{mg}$ of antibodies diluted in $5 \mathrm{ml}$ of buffered phosphate solution, $\mathrm{pH} 7.2$ was added to an active hematoporphyrin -linker complex. The obtained mixture stayed for 5 hours with periodical stirring. During this procedure $\mathrm{pH}$ of the mixture was adjusted to 6.0-7.0. To stop the reaction $50 \mu \mathrm{l}$ of monoethanolamine was added at the end of the incubation period (5hours).

The mixture was left at room temperature for 12 hours and then dialyzed against the solution of water: dimethyl sulfoxide, 2.5:0.5, for 72 hours, the dialysis solution being periodically changed. After dialysis the obtained conjugate was lyophilized. Absorption spectrum was registered using Nano Drop spectrophotometer, USA.

Immunoconjugate phototoxicity was determined in the model of photoinduced erythrocyte haemolysis due to hematoporphyrin activity of the complex [1]. Blood of healthy rats was washed three times in physiological solution and PBS, ratio 1:5. After washing the erythrocyte fraction was centrifuged at $500 \mathrm{~g}$ for $5 \mathrm{~min}$. The pellet was diluted in PBS, 1:20(volume/volume). Each probe contains $200 \mu \mathrm{l}$ of the diluted erythrocyte suspension and $150 \mu 1$ of PBS. Experimental probes contain $50 \mu$ l of the investigated conjugate. Control probes contain $50 \mu 1$ of hematoporphyrin stock solution (20 $\mathrm{mg}$ of hematoporphyrin was diluted in $3 \mathrm{ml}$ of the mixture water:dimethyl formamide, 2.5:0.5). To determine photosensibilizator dark activity some of the experimental and control probes were kept in the darkness. Experimental probes were irradiated by the ordinary illuminator, light intensity till $1.5 \mathrm{mWt}$ per $\mathrm{cm}^{2}$ for $5 \mathrm{~min}$ with periodical stirring. After irradiation the samples were centrifuged at $500 \mathrm{~g}$ for $5 \mathrm{~min} .100 \mu \mathrm{l}$ of the supernatant were added to $900 \mu \mathrm{l}$ of Drobkin reagent (test-system for quantitative hemoglobin determination). The amount of hemoglobin, which was released as a result of erythrocyte damage by hematoporphyrin, was measured with spectrophotometer at $540 \mathrm{~nm}$. A calibration curve was made according to the test-system instruction.

A specific activity of anti-VEGF antibodies in their conjugates with porphyrin compounds ( one of the main characteristics of the obtained complex) was estimated by ELISA with VEGF as an antigen [15]. The antigen was adsorbed on the plate, 10ng per well.

The level of conjugate accumulation in the neo-angiogenesis zone was analyzed on the chicken embryo chorioallantoic membrane. Photosensibilizators $(2 \mathrm{mg}$ per $\mathrm{kg}$ ) were injected into allantois of embryo at $6^{\text {th }}$ and $10^{\text {th }}$ day of the development [17]. In 24 hours after photosensibilizator injection, when hematoporphyrin was injected to control group and conjugate with VEGF antibodies to experimental one, chorioallantoic membranes were extracted, homogenized in $0.1 \mathrm{M} \mathrm{NaOH}(3 \mathrm{ml} / 0.5 \mathrm{~g}$ of tissue $)$ and centrifuged at $15,000 \mathrm{~g}$ for $20 \mathrm{~min}$. The content of photosensibilizator agent, hematoporphyrin, was determined in the supernatants by the spectrophotometer method at $505 \mathrm{~nm}$.

Results and Discussion. The absorption spectra of the investigated conjugate did not reveal any essential changes in absorption of both: porphyrin and protein component of the complex as compared with the absorption spectra of the minor component i.e. hematoporphyrin (see Fig.1). It is known that porphyrin compounds can absorb at 390-600nm with the absorption peak at $505 \mathrm{~nm}$. The spectrum has 4 lines, one of which, Sare line is a characteristic feature of the porphyrin compounds. The conjugates obtained had the same absorption region of 390-600nm with 


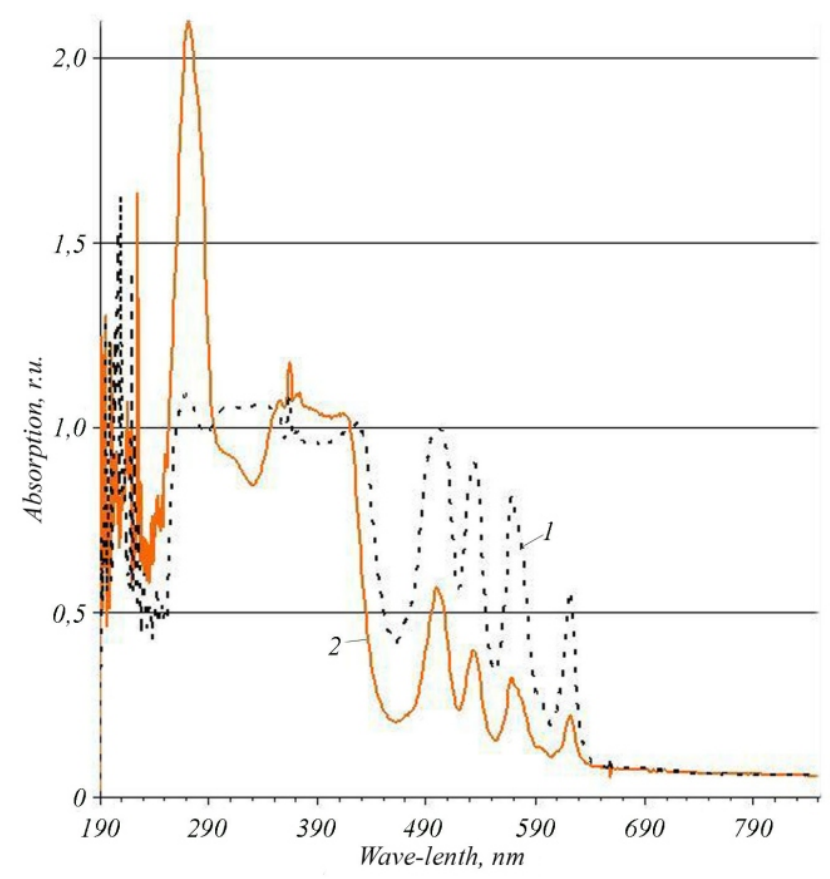

Fig. 1. The absorption spectra of hematoporphyrin (1) and conjugate of hematoporphyrin with antibodies against VEGF (2)

Sare line also present. According to the comparison of spectra no essential changes were found in physical properties of porphyrin compound of the conjugate and hematoporphyrin itself. The protein component of the conjugate, i.e. antibody, did not seem to change either.

In full absorption spectrum, 190-690nm, we could observe constant absorption peak at $260 \mathrm{~nm}$, which is an exact protein characteristic. Therefore, the conjugate composed of hematoporphyrin photosensibilizator and polyclonal antibodies to EGF practically does not lose the absorption properties of the original components i.e. antibodies and hematoporphyrin.

Molar ratio of hematoporphyrin and antibodies equal to 4.2 was determined by absorption at 505 and $280 \mathrm{~nm}$ correspondingly.

Investigating the immunoconjugate phototoxicity we found that equivalent amount of the conjugate and original photosensibilizator, hematoporphyrin had the same activity in erythrocyte haemolysis (Fig.2). Noteworthy, that in the probes, which stayed in the darkness, the erythrocyte haemolysis reaction was not observed. It can evidence, that the conjugate does not possess dark phototoxicity.

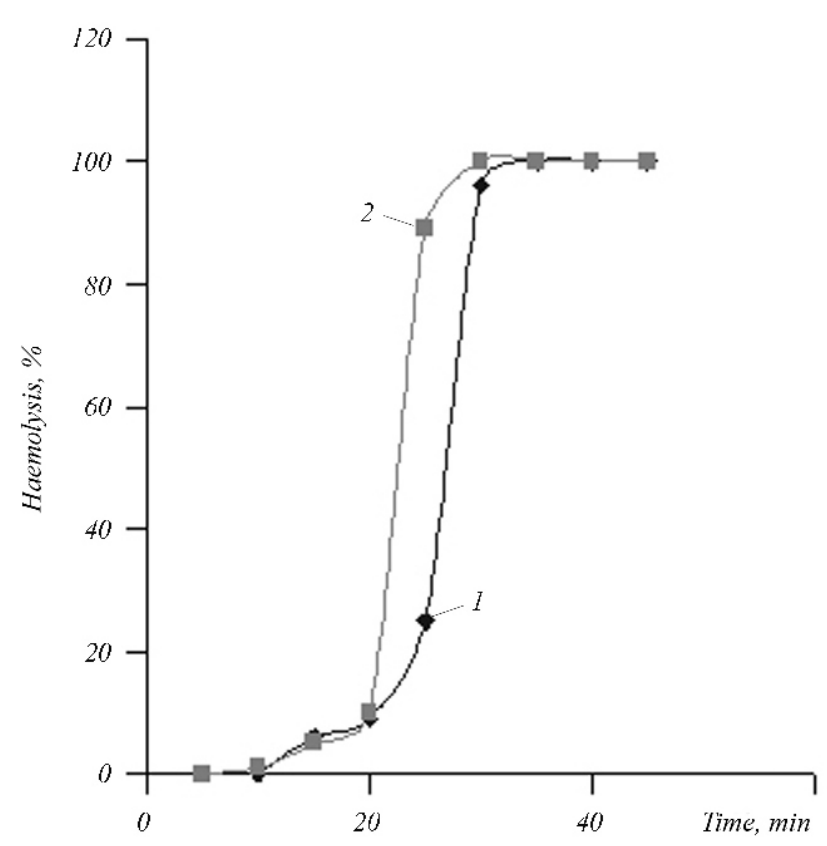

Fig. 2. The hemolytic activity of hematoporphyrin conjugated with antibodies against VEGF (1) and stock hematoporphyrin (2),was determined in the model of photoinduced erythrocyte haemolysis

Specific antibody activity in the conjugates with porphyrin compounds is one of the main characteristic of such complexes. The investigation showed that the conjugate formation between hematoporphyrin with VEGF antibodies using carbodiimide as a linker made influenced essentially on the specific antibody activity in the conjugates. The titer of these antibodies in the ELISA antigen-antibody test was 12,800 that are twice less than the titer non-conjugated antibodies - 25,600 (Fig.3).

The study on specific conjugate accumulation in neoangiogenesis zones of chicken embryo showed an essential difference in the accumulation of photoactive compound by the vascular system of chorioallantoic membrane on the $6^{\text {th }}$ and $10^{\text {th }}$ day of the development (Fig.4).

It is known, that on the $6^{\text {th }}$ day the chorioallantoic membrane of the embryo is characterized by maximal endothelium proliferation and capillary formation. However on the $10^{\text {th }}$ day of the development we could notice stabilization of neovascular processes in membranes. In 24 hours after the conjugate injection the different level of photosensibilizator accumulation could be observed in the chorioallantoic membranes. On the 


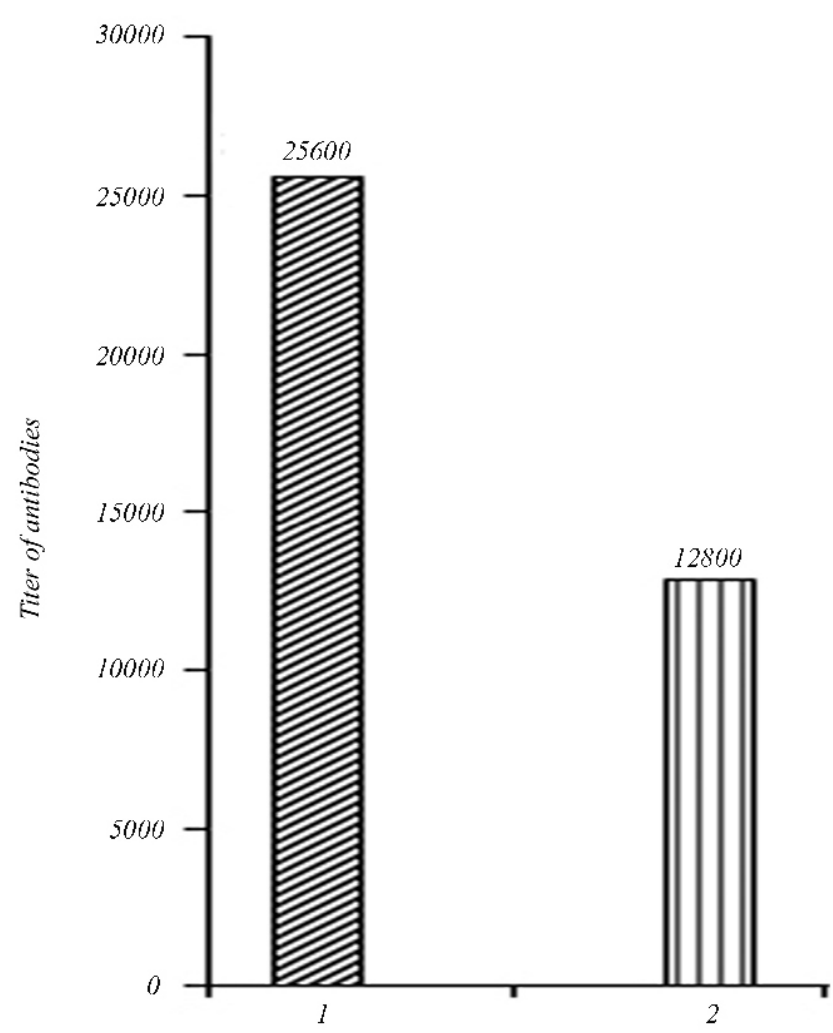

Fig. 3. The titer of anti-VEGF antibodies in the ELISA antigen-antibody test:: 1 - non-conjugated antibodies; 2 conjugates with hematoporphyrin

$6^{\text {th }}$ day of the embryo development it was accumulated in 2.5 times more hematoporphyrin conjugated with VEGF antibodies in comparison with the embryo of the $10^{\text {th }}$ day of the development. Because the latter is characterized by the stabilization of neovascular processes, these data denoted vasotropic effect in the way of photosensibilizator accumulation. It happened as a result of photosensibilizator targeting immediately into the zones of active angiogenesis. The chorioallantoic membranes on the $6^{\text {th }}$ day of the development just may be considered as such zones.

The sense of PDT is introduction of photosensibilizators into an organism containing tumor for their selective accumulation by tumor cells. However, the photosensibilizators, which are currently used in oncology, do not posses such selectivity. There is a real way to make them selective: to create conjugates on the base of photoactive compounds and biologically active substances. These conjugates should provide targeting of photosensibilizators towards tumor cells. The

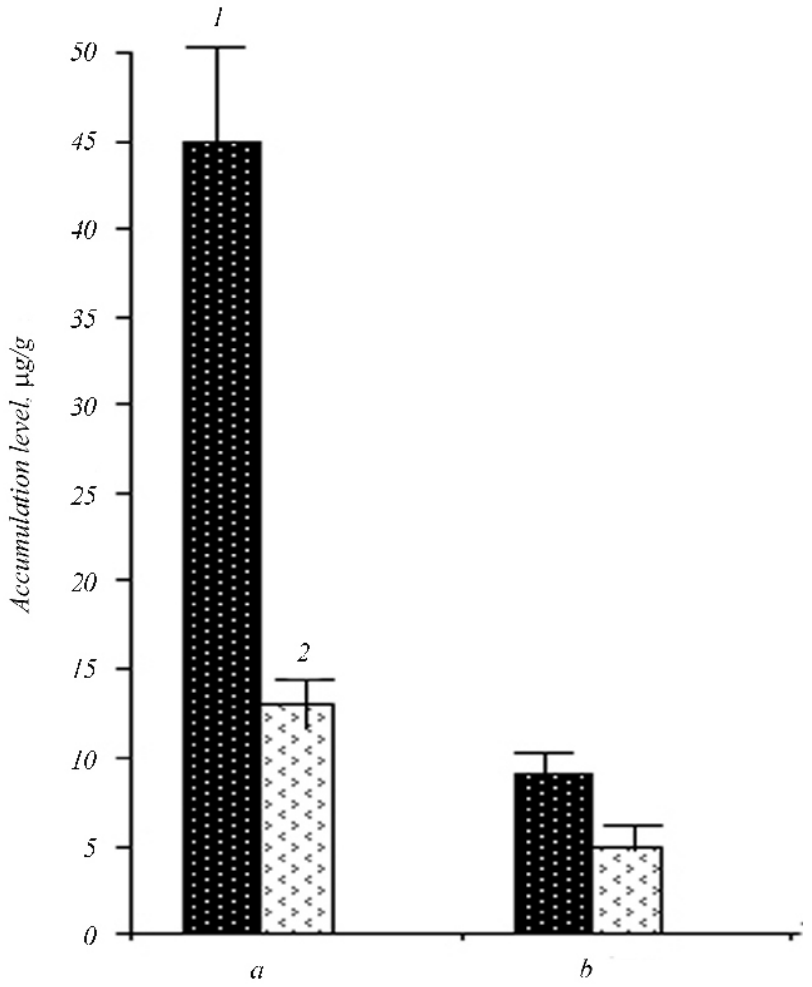

Fig. 4. The accumulation of hematoporphyrin conjugated with VEGF antibodies $(a)$ and stock hematoporphyrin in chicken embryo chorioallantoic membranes on the $6^{\text {th }}$ and $10^{\text {th }}$ day of the development

tumor vascular system could be an efficient target for such purpose.

Our study on the chorioallantoic membranes of chicken embryo has shown that the photoactive conjugate of hematoporphyrin with VEGF antibodies is able to accumulate just in the zones of active development of capillary net in embryo membranes. After neo-angiogenesis stabilization $\left(10^{\text {th }}\right.$ day of the embryo development) the accumulation of photoactive conjugate by membranes was sharply decreased. Taking into consideration these results we can state that the obtained conjugated photosensibilizator has vasotropic properties. This allows us to develop the method to provide photodynamic targeting action on the neoplasm vascular system through angiogenically activated endothelial cells, which take part in the formation of neovascularization zones during the tumor development, further growth and metastasis.

The preference of endothelial cells as targets for tumor treatment can be explained by the expression on 
their surface of the receptors for angiogenesis cytokines, particularly EGF.

The application of such variant of targeting PDT could strengthen the photodynamic anti-tumor effect while decreasing the dosage of the injected photosensibilizators and lowering the level of their toxicity.

Conclusions. 1. The photoactive bioconjugate of VEGF antibodies with photosensibilizator, hematoporphyrin, has been obtained.

2 . The conjugate practically does not lose physical and biological properties, which are characteristic of its protein component, antibodies, and its porphyrin component, hematoporphyrin.

3 . It has been shown that the conjugate accumulation in the chorioallantoic membranes of chicken embryo with the maximal endothelium proliferation (on the $6^{\text {th }}$ day of the embryo development) was 2.5 times higher in comparison with the embryo membranes on the $10^{\text {th }}$ day of the development i.e. the period of stabilization of neo-vascular processes .

\section{І. О. Лісняк, Н. Л. Новиченко, А. А. Мамчур, М. Ф. Гамалія}

Отримання та властивості фотоактивного імунокон'югату гематопорфірину з антитілами до фактора росту ендотеліальних клітин

Резюме

Описано метод отримання фотоімунокон 'югатів на основі гематопорфірину та антитіл, специфічних до фактора росту ендотеліальних клітин (VEGF). Одержаний кон'югат зберігає фізико-хімічні та біологічні властивості як білкового компонента кон'югату, так $і$ порфіринової складової - гематопорфірину. Показано, что накопичення фотоімунокон'югату з антитілами до VEGF у мембранах курячих ембіронів виявилося в 2,5 разу вищим у період неоваскуляризаиії, яка розвивається, порівняно з періодом стабілізації.

Ключові слова: фотодинамічна терапія, ангіогенез, кон'югати, гематопорфірин, VEGF.

\section{И. А. Лисняк, Н. Л. Новиченко, А. А. Мамчур, Н. Ф. Гамалея}

Получение и свойства фотоактивного иммуноконъюгата гематопорфирина с антителами к фактору роста эндотелиальных клеток

Резюме

Описан метод получения фотоиммуноконъюгатов на основе гематопорфирина и антител, специфичных к фактору роста эндотелиальных клеток (VEGF). Полученный конъюгат сохра- няет физико-химические и биологические свойства как белкового компонента конъюгата, так и порфириновой составляющей - гематопорфирина. Показано, что накопление фотоиммуноконъюгата с антителами к VEGF в мембранах куриных эмбрионов было в 2,5 раза выще в период развивающейся неоваскуляризации по сравнению с периодом стабилизации.

Ключевые слова: фотодинамическая терапия, ангиогенез, конъюгати, гематопорфирин, VEGF.

\section{REFERENCES}

1. Mew D., Wat C. K., Towers G. H., Levy J. C. Photoimmunotherapy treatment of animal tumors with tumo-specific monoclonal antibody - hematoporphyrin conjugates // J. Jmmunol.-1983.-130, N 3.-P. 1473-1477.

2. Jiang F. N., Richter A. M., Jain A. K., Levy J. G., Smith C. Biodistribution of a benzoporphyrin derivative-monoclonal antibody conjugate in A 549 - tumor-bearing nude mice // Biotechnol. Ther.-1993.-4, N 1-2.-P. 43-61.

3. Carcenac M., Larrogue C., Langlois R., van Lier J., Artus J., Pelegrin A. Preparation, phototoxicity and biodistribution studies of anti-carcinoembryonic antigen monoclonal antibody - phthalocyanine conjugates // J. Photochem. Photobiol.-1999.-70, N 6.-P. 930-936.

4. Vrouenraets M. B., Visser G. W., Stigter M., Oppelaar H., Snow G. B, van Dongen G. A. Comparison of aluminium (III) phthalocyanine tetrasulfonate- and meta-tetrahydroxyphenylchlorin-monoclonal antibody conjugates for their efficacy in photodynamic therapy in vitro // Int. J. Cancer.-2002.-98, N 5.-P. 793-798.

5. Fabbrini M., Trachsel E., Soldani P., Bindi S., Alessi P., Bracci L., Kosmehl H., Zardi L., Neri D., Neri P. Selective occlusion of tumor blood vessels by targeted delivery of an antibody-photosensitizer conjugate // Int. J. Cancer.-2006.118, N 7.-P. 1805-1813.

6. Sharman W. M., van Lier J. E., Allen C. M. Targeted photodynamic therapy via receptor mediated delivery systems // Adv. Drug Deliv. Rev.-2004.-56, N 1.-P. 53-76.

7. Governatore M., Hamblin M. R., Shea C. R., Rizvi I., Molpus K. G., Tanabe K. K., Hasan T. Experimental photoimmunotherapy of hepatic metastases of colorectal cancer with a 17.1 A chlorin e6 immunoconjugate // Cancer Res.-2000.-60.P. 4200-4205.

8. Linares R., RachecoY. R., Good T. A. Efficacy of different targeting agents in the photolysis of interleukine-2 receptor bearing cells // J. Photochem. Photobiol.-2004.-77, N 1-3.P. 17-26.

9. Giysene A., Missiaen L., Wilfried M., Witte P. Epidermal growth factor-mediated targeting of chlorine e6 selectively potentiates its photodynamic activity // Cancer Res.-2000.60, N 8.-P. 2197-2202.

10. Savellano M., Pogue B., Hoopes P., Vitetta E., Paulsen K. Multiepitope HER2 targeting enhances photoimmunotherapy of HER2-overexpessing cancer cells with pyropheophorbide - immunoconjigates // Cancer Res.-2005.-65, N 14.P. 6371-6379.

11. Soukos N., Hamblin M., Keel S., Fabian R., Deutsch T., Hasan $T$. Epidermal growth factor receptor-targeting immunophotodiagnosis and photoimmunotheraphy of oral precancer in vivo // Cancer Res.-2001.-61, N 11.-P. 4490-4496. 
12. Gijsens A., De Witte P. Targeting of chlorine E6 by EGF increasing its photodynamic activity in selective ways // Verth. K Acad. Geneeskd. Belg.-2000.-62, N 4.-P. 329-352.

13. Gupta S., Mishra A. K., Muralidhar K., Jain V. Improved targeting of photosensitizers by intratumoral administration of immunoconjugates // Technol. Cancer Res. Treat.-2004.-3, N 3.-P. 295-301.

14. Chen B., Pogue B. W., Luna J. M., Hardman R. L., Hoopes P. $J$., Hasan T. Tumor vascular permeabilization by vasculartargeting photosensitization: effects, mechanism, and therapeutic implications // Clin. Cancer Res.-2006.-12, N 3.P. 917-923.
15. Иммунологические методы / Под ред. Г. Фриммеля.-М.: Медицина, 1987.-518 с.

16. Лісняк I. О. Неоваскуляризація і пухлинний ріст: Автореф. дис. д-ра біол. наук.-Київ, 2004.-38 с.

17. Roberts $W$., Hasan T. Role of neovascularization and vascular permeability on the tumor retention of photodynamic agents // Cancer Res.-1992.-52, N 4.-P. 924-930.

UDC 616-006.04:615.37:577.112.85

Received 04.02.08 